\title{
ONLINE GROUP DISCUSSION PADA MATA KULIAH TEKNOLOGI PEMBELAJARAN FISIKA
}

\author{
Yuberti \\ Program Studi Pendidikan Fisika, FTK IAIN Raden Intan Lampung; Email: yuberti_iain@yahoo.co.id
}

Diterima: 19 Agustus 2015 Disetujui: 11 Oktober 2015. Dipublikasikan: Oktober 2015

\begin{abstract}
Nowadays, gadged just like handphone and notebook more reachable so the quantities of the users are increase in Indonesia. It is common for us to see the students, employees, enterpreneurs until housewives using gadged anywhere and anytime. This phenomenon is spread widely along with the internet wifi and hotspot in many places start from official educational institute, government, and office centre, to the tourism object and shopping center. Also with internet café (Warnet) compete tightly with offering various facilities, and services with compete price. All cellphone service is also giving internet access in order to attract users. Some phenomena show more and more people who use the Internet and make it as a lifestyle for berintaksi, socialize, learn and get information. Widespread use of the Internet can be a great potential in the development of online learning system allows learners to access the information flexibly without limitation of time and place. Discussion no longer occur face to face, but can continue even in the virtual environment. As the implementation of other virtual learning methods. Implementation of online discussion itself is basically adopting the method of learning face to face discussion.
\end{abstract}

Abstrak: Harga gadged seperti handphone dan notebook kian hari kian terjangkau sehingga jumlah penggunanya di indonesia terus meningkat. Bukanlah suatu yang asing jika kita menjumpai para siswa, mahasiswa, karyawan, pengusaha hingga ibu rumah tangga menggunakan gadged dimana saja dan kapan saja. Fenomena ini diiringi dengan meluasnya jaringan internet nirkabel seperti hotspot dan wifi di berbagai tempat mulai dari institusi resmi pendidikan, pemerintahan, dan perkantoran, hingga tempat wisata,dan pusat perbelanjaan. Tidak mau ketinggalan warnet (warung internet) ikut bersaing ketat dengan menawarkan berbagai macam fasilitas, dan layanan dengan harga bersaing. Seluruh layanan seluler ponsel juga terus memberikan penawaran akses internet yang menggiurkan demi menarik minat penggunanya. Beberapa fenomena tersebut menunjukkan semakin banyak kalangan yang memanfaatkan internet dan menjadikanya sebagai gaya hidup untuk berintaksi, bersosialisasi, belajar dan mendapatkan informasi. Meluasnya pemanfaatan internet bisa menjadi potensi besar dalam pengembangan pembelajaran dengan sistem online memungkinkan pebelajar untuk mengakses infromasi secara fleksibel tanpa terbatas waktu dan tempat. Diskusi tidak lagi terjadi secara tatap muka, namun dapat terus berlangsung meskipun dalam lingkungan maya. Sebagaimana pelaksanaan metode pembelajaran maya lainnya. Pelaksanaannya diskusi online itu sendiri pada dasarnya mengadopsi dari metode pembelajaran diskusi tatap muka.

Kata kunci: online group discussion, teknologi pembelajaran

\section{PENDAHULUAN}

Teknologi informasi dan komunikasi bukan lagi milik orangorang tertentu melainkan milik semua orang, mulai dari lapisan bawah hingga teratas. Bahkan saat ini, sebagian besar orang tidak bisa lepas dari teknologi tersebut. Meluasnya 
pemanfaatan internet bisa menjadi potensi besar dalam pengembangan pembelajaran dengan sistem online. Pembelajaran dengan sistem online memungkinkan pebelajar untuk mengakses informasi secara fleksibel tanpa terbatas waktu dan tempat. Istilah "belajar online" (online learning) memiliki banyak padanan istilah yang sering digunakan seperti e-learning, internet learning, distributed learning, networked learning, tele-learning, Online learning, compter-assited-learning, web-based learning, distance learning). Semua istilah tersebut merujuk pada adanya jarak antara pebelajar dan pemelajar, dimana pebelajar memanfaatakan teknologi komputer untuk mengakses materi pelajaran, berinteraksi dengan pemelajar dan pebelajar lainnya, dan memperoleh beberapa bentuk bantuan yang tersedia.

Untuk mengangkat pembelajaran bermakna diperlukan Interactivity penting dalam Online Learning karena interaksi antar muka dalam Online Learning adalah dengan komputer yang digunakan untuk mengakses isi materi pelajaran dan untuk berinteraksi dengan orang lain. Pembelajaran online menawarkan berbagai keuntungan seperti kesempatan belajar yang lebih fleksibel tanpa terikat ruang dan waktu (Kusumaningrum, 2014). Sebagaimana peserta didik dalam Online Learning berinteraksi dengan isi, mereka harus didorong untuk menerapkan, menilai, menganalisis, mensintesis, mengevaluasi, dan merefleksi apa yang mereka pelajari. Sementara adaptivity mensyaratkan sistem komputer yang secara otomatis menyesuaikan diri dengan penggunaannya beserta karakteristik lingkungannya.

Metode pembelajaran Online merupakan satu dari sekian banyak inovasi yang telah dihasilkan dari teknologi pendidikan. Sebab, metode ini mampu mengakomodasi keterbatasan jarak, waktu, dan tempat untuk belajar. Sebagaimana landasan epistemologi teknologi pendidikan itu sendiri bahwa belajar bisa dilakukan kapan saja dan dimana saja dan oleh siapa saja.

Perguruan tinggi di Indonesia semakin banyak yang memanfaatkan metode Online Learning dengan tujuan yang berbeda-beda. Satu dari sekian banyak mata kuliah yang ditawarkan,mata kuliah teknologi pendidikan mencoba untuk mengimplementasikan metode ini. Pembelajaran Online yang selama ini tersedia pada berbagai universitas banyak dikembangkan dengan menggunakan learning management System (LCMS) yang sudah banyak tersedia baik yang bersifat berbayar seperti atutor, maupun yang bersifat gratis seperti misalnya moodle dan Claroline. Semua LMS/LCMS tersebut mempunyai kelebihan dan kekurangan tersendiri dimana para pengembang tinggal memuntuskan mana yang sesuai dengan kebutuhan belajar mereka. Dengan pertimbangannya tersendiri, Web-Bali diputuskan menggunakan LCMS Claroline yang merupakan singkatan 
dari classroom online. Sebagaimana platform LCMS lainnya, Claroline memfasilitasi berbagai macam fitur pembelajaran online seperti misalnya fitur diskusi, fitur chat, fitur agenda, fitur latihan, fitur latihan dimana semuanya berada dalam satu alur pembelajaran.

Dari banyaknya fasilitas yang telah tersedia, penulis menemukan masih ada beberapa fitur yang belum dimanfaatkan secara maksimal. Seperti pemanfaatan Online group discussion atau online group discussion yang bisa dikategorikan sebagai metode diskusi tidak langsung (asynchronous). Grup diskusi online merupakan sebuah kegiatan diskusi yang dilakukan dalam jejaring internet. Mata kuliah teknologi Pendidikan banyak menggunakan strategi diskusi baik secara tatap muka maupun secara maya atau online karena mata kuliah ini banyak yang mengandung ragam pengetahuan konsep yang membutuhkan pandangan dan pendapat pribadi dari setiap peserta belajar untuk menghasilkan pengetahuan baru bersama.

Seperti kita ketahui bersama, saat ini diskusi tidak lagi terjadi secara tatap muka, namun dapat terus berlangsung meskipun dalam lingkungan maya. Sebagaimana pelaksanaan metode pembelajaran maya lainnya. Pelaksaannya diskusi online itu sendiri pada dasarnya mengadopsi dari metode pembelajaran diskusi tatap muka. Para pebelajar dan fasilitator tidak diharuskan hadir dalam satu tempat yang sama, tidak harus ketemu secara langsung namun tetap dapat bertukar pikiran dan informasi melalui fasilitas yang terdapat dalam website.

Penelitian ini merupakan kajian pendahuluan dari online learning berdasarkan studi literatur yang ada. Beberapa studi tentang online learing menunjukkan bahwa pembelajaran ini bisa meningkatkan pemahaman mahasiswa (Asalla, 2014) dan meningkatkan motivasi dan prestasi (Djuniadi, 2012)

\section{PEMBAHASAN}

Hadirnya teknologi pada saat ini membawa segala urusan kehidupan manusia menjadi lebih baik dan menjadi lebih mudah. Jelas terlihat peran hadirnya teknologi, tetapi dibalik peran yang begitu 'maha', sangat kita sadari juga bahwa tantangannya akan hadir secara bersamaan. Oleh sebab itu, apabila kita memahami peran teknologi maka kita semaksimal mungkin memanfaatkannya, demikian juga apabila kita mengetahui tantangannya, maka kita akan mempersiapkan diri terhadap tantangan tersebut.

Adanya teknologi yang terjadi pada saat ini telah membuka jalan bagi para pendidik dan juga teknolog pendidikan untuk mengkaji ulang masalah-masalah yang timbul dalam bidang pendidikan yang ada pada saat ini. Bila pada masa lalu banyak masalah pendidikan yang belum terselesaikan, maka pada masa sekarang masalah pendidikan menjadi semakin kompleks, karena seiring dengan perkembangannya zaman. Romiszowski dalam Suroyo (2006) 
menyampaikan bahwa saat ini terdapat ratusan perguruan tinggi maya yang menyebar di seluruh dunia. Data tersebut menunjukkan bahwa peminat pembelajaran online learning terus meningkat dari tahun ke tahun. Pada tahun 2003, jumlah pebelajar online telah mencapai 6.976 orang dari 67 negara seperti Singapura, Malaysia, Hongkong, Afrika Selatan, UAE, India, Jerman, dan Kanada. Kemudian meningkat menjadi 7.707 orang pada 2007 termasuk pebelajar online dari Indonesia. Data ini juga terdiri dari 100.000 mahasiswa yang terdaftar. Perguruan tinggi seperti ini dirancang dalam rangka memberikan kursus belajar dalam jumlah besar, menggunakan teknik pembelajaran jarak jauh dan juga membuat program pembelajaran dengan biaya efektif. Sekitar 15 perguruan tinggi (Universitas) telah masuk dalam kategori mega universitas, namun baru tujuh universitas yang masuk dalam kategori Super Mega Universitas, salah satunya adalah Universitas Terbuka (UT) Indonesia.

Munculnya fenomena ini memungkinkan bertambah tingginya daya saing antar universitas di masa yang akan datang. Sehingga sudah selayaknya setiap universitas di Indonesia, selayaknya untuk mempersiapkan diri dengan memberikan layanan terbaik dan membangun infrastruktur agar dapat bersaing dengan universitas lain, sehingga dapat menampung mahasiswa dalam jumlah besar sebagai lapisan masyarakat sebagaimana yang tertera dalam
Undang-undang sistem pendidikan Nasional No 20 Tahun 2003 pasal 31 tentang Pendidikan Jarak Jauh.

Persiapan sebelum memberikan layanan belajar merupakan salah satu faktor penentu dalam keberhasilan belajar, terutama pada Online Learning dimana adanya jarak antar pebelajar dan pembelajar. Pembelajar ini harus mengetahui prinsip-prinsip belajar dan bagaimana pebelajar belajar. Alat penyampaian bukanlah faktor penentu kualitas belajar, melainkan desain mata pelajaran menentukan keefektifan belajar. Dengan demikian, maka dapat dinyatakan bahwa dalam merancang materi belajar Online, tidak ada satu teori saja yang harus diikuti melainkan harus menggunakan kombinasi beberapa teori. Pengembangan materi harus mengetahui pendekatan agar memilih strategi pembelajaran yang tepat. Salah satu alasan pemilihan strategi pembelajaran adalah untuk mengangkat pembelajaran yang bermakna (Gredler, 2009).

Teknologi informasi saat ini berkembang begitu cepat (Smaldino, 2007). Kebutuhan akan sebuah informasi terasa sangat penting oleh karena itu dibutuhkan sebuah sarana diskusi yang membahas permasalahan yang dihadapi saat ini. Online Grup Diskusi merupakan suatu sistem pembelajaran dan diskusi tentang suatu masalah yang berbasis berbasis sebuah website. Seseorang bisa berperan sebagai media pembelajaran dan memberikan saran atau gagasan tentang suatu permasalahan (Smaldino, 2007). Bagi anda yang 
ingin berbagi informasi, anda dapat diberi hak untuk menjadi komentator, sehingga anda dapat membuat dan mengelola suatu topik diskusi secara online. Bagi pengunjung yang lain dapat mengakses materi pembelajaran yang sudah tersedia serta menjalin komunikasi dengan para pengunjung lainnya.

Selain itu, materi yang disajikan dapat didownload dengan mudah tanpa syarat apapun. Kelebihan dari online grup diskusi ini antara lain: aplikasi berbasis client-server sehingga mendukung penggunaan lebih dari 1 komputer dan multi user. Semua pengguna dapat menjadi komentator atau pemecah masalah belajar. selalu up to date user friendly. Kemudahan pemakaian karena desain user interface (tampilan) dan alur pemakaian mudah dipahami. Ruang lingkup masalah dari perancangan online grup diskusi ini adalah perancangan model, forum perancangan alur pengguna, serta perancangan dan penjelasan dari online grup diskusi pembelajaran.

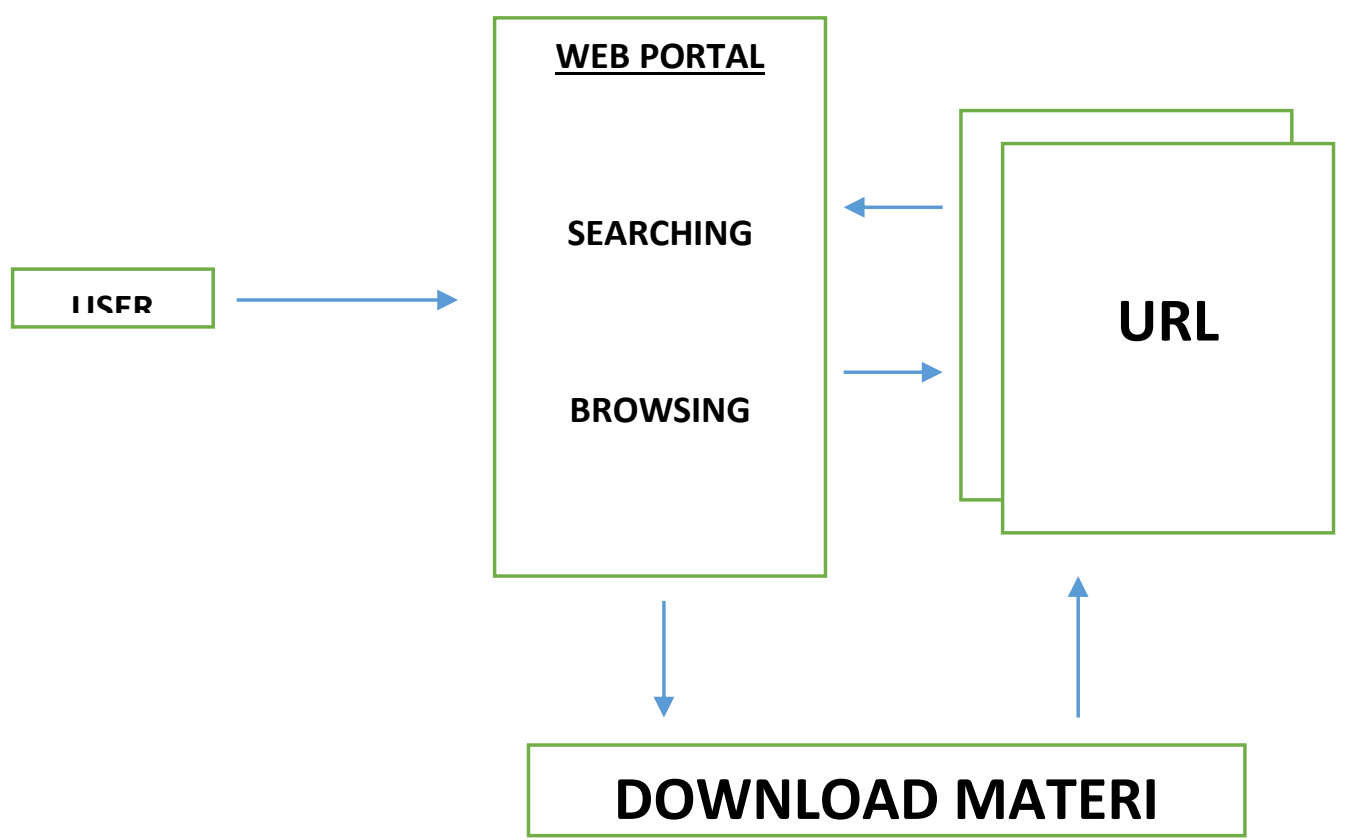

\section{Gambar 1. Alur Grup Diskusi Online}

Teknologi

merupakan disiplin ilmu terapan, artinya ia berkembang karena adanya kebutuhan di lapangan, dengan kata lain adalah kebutuhan belajar (Prawiradilaga, 2013). Penerapan teknololgi pendidikan dalam pembelajaran dimaksudkan agar belajar lebih efektif, efisien, lebih banyak, lebih luas, lebih cepat dan lebih bermakna bagi kehidupan orang yang belajar. Ditinjau dari pengertian teknologi secara umum adalah proses yang dapat meningkatkan nilai tambah produk yang digunakan dan dihasilkan untuk memudahkan dan meningkatkan kinerja stuktur, yang dimana proses dan produk tersebut dikembangkan 
dan digunakan, semua bentuk teknologi adalah sistem yang diciptakan oleh manusia untuk maksud dan tujuan tertentu untuk mempermudah manusia dalam meringankan usahanya, meningkatkan hasilnya, dan menghemat tenaga dan sumber daya yang ada.

Menelusuri pandangan Al-Qur'an tentang teknologi, mengundang kita kepada sekian banyak ayat Al-Qur'an yang menjelaskan alam raya. Menurut para Ulama terdapat sekitar 750 ayat Al-Qur'an yang berbicara tentang alam raya dan fenomenanya, dan memerintahkan manusia untuk mengetahui dan memanfaatkannya. Secara tegas dan berulang-ulang, AlQur'an menyatakan bahwa alam raya diciptakan dan ditundukkan Allah untuk manusia.

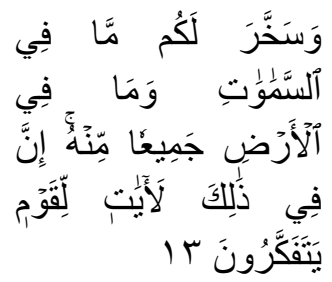

Dan Dia telah menundukkan untukmu apa yang di langit dan apa yang di bumi semuanya, (sebagai rahmat) daripada-Nya. Sesungguhnya pada yang demikian itu benar-benar terdapat tanda-tanda (kekuasaan Allah) bagi kaum yang berpikir.

(QS. Al Jatsyiah : 13)

Adanya potensi dan tersedianya lahan yang diciptakan Allah, serta ketidakmampuan alam raya untuk membangkang perintah-Nya, kesemuanya mengantarkan manusia berpotensi untuk memanfaatkan sebaik mungkin. Keberhasilan memanfaatkan alam itulah buah teknologi.

Aspek pendidikan adalah aspek terpenting dalam membentuk karakter bangsa. Dengan mengukur kualitas pendidikan, maka kita dapat melihat potret bangsa yang sebenarnya, karena aspek pendidikanlah yang menentukan masa depan seseorang, apakah dia dapat memberikan suatu yang membanggakan bagi bangsa dan dapat mengembalikan jati diri bangsa atau sebaliknya. Peningkatan mutu pendidikan semakain diarahkan pada perluasan inovasi pembelajaran baik pada pedidikan formal maupun nonformal dalam rangka mewujudkan proses yang efisien, menyenangkan dan mencerdaskan sesuai tingkat usia, kematangan, serta tingkat perkembangan peserta didik.

Sebagai bidang Teknologi Pendidikan merupakan penerapan teori dan praktik secara terpadu mencakup kelima domain atau kawasan, yaitu Design, Development, Utilization, Management, Evaluation. (Miarso, 2004). Bidang kegiatan tersebut semuanya tertuju untuk memecahkan masalah belajar manusia. Sebagai profesi Teknologi Pendidikan terbentuk dari usaha yang direncanakan secara sistematis (terorganisir) guna melaksanakan teori, teknik intelektual dan penerapan praktis Teknologi Pendidikan. Sebagaimana konsep yang tertera pada Associate Educational Comunication and Technology (AECT), berikut ini: Educational technology is the study and ethical practice of facilitating learning and improving performance 
by creating, using, and managing appropriate technological processes and resources.

Perkembangan ilmu dan teknologi merupakan salah satu hasil produktivitas dari manusia yang memiliki pengetahuan yang didapat dari pendidikan. Dimana perkembangan ilmu pengetahuan dan teknologi memiliki implikasi yang luas dalam kehidupan manusia sehingga diharapkan manusia manusia tersebut perlu mendalami untuk mengambil manfaatnya secara optimal dan mereduksi implikasi negatif yang ada. Mendalami serta mengambil manfaat dari perkembangan ilmu pengetahuan dan teknologi tidak mungkin dilakukan oleh semua manusia dalam kapasitas dan dengan waktu yang sama. Keterbatasan manusia dan waktu tersebut menuntut adanya spesialisasi.

Pengetahuan tentang hal terakhir ini mengantar ilmuan kepada rahasiarahasia alam, dan pada gilirannya mengantarkan pada penciptaan teknologi yang menghasilkan kemudahan dan manfaat bagi manusia. Disini kita menoleh kepada teknologi dan hasil-hasil yang telah dipersembahkannya. Kalau lah untuk mudahnya kita jadikan alat atau mesin sebagai gambaran kongkrit tentang teknologi. Mesin-mesin dari hari ke hari semakin canggih. Mesin-mesin tersebut dengan bantuan manusia bergabung satu dengan lainnya. Sehingga ia semakin kompleks, ia tidak bisa lagi dikendalikan oleh seorang, namun ia dapat melakukan pekerjaan yang dilakukan banyak orang. Dalam tahap ini, mesin telah menjadi semacam "seteru" manusia, atau hewan yang harus disiasati agar ia mau mengikuti kehendak manusia. Dewasa ini, lahir teknologi, khususnya dibidang rekayasa genetika, yang dapat mengarah untuk menjadikan alat sebagai bantuan, bahkan menciptakan bakal-bakal alat yang akan diperbudak dan tunduk kepada alat. Tetapi jika hasil teknologi sejak semula diduga dapat mengalihkan manusia dari asal tujuan penciptaan, maka sejak dini Islam menolak kehadiran hasil-hasil teknologi.

Dengan segala fasilitas yang tersedia pada platform yang digunakan, ini rasanya bukanlah hal yang mustahil untuk menerapkan diskusi belajar secara online mengingat diskusi merupakan salah satu strategi pembelajaran yang dapat dimanfaatkan untuk membangun pengetahuan bagi pebelajarnya. Namun demikian, penerapannya harus sesuai dengan pendekatan teori yang mendukungnya dan fitur yang akan dijadikan acuan untuk menjalankannya.

Seperti diketahui bersama, beberapa manfaat dari pembelajaran online yaitu meningkatkan pemahaman dan motivasi pengguna (Asalla, 2014; Djuniadi, 2012). Pembelajaran online juga dapat mengasah keterampilan peserta (siswa/mahasiswa) menggunakan teknologi.

Dengan mengetahui besarnya manfaat yang dihasilkan dari belajar melalui diskusi, maka pada mata kuliah teknologi pendidikan akan 
segera mungkin menerapkan serta memanfaatkan Online group discussion yang ada didalamnya, kendati masih terbilang sudah memanfaatkan selama satu tahun lebih sejak peluncurannya, penulis ingin mengetahui apakah pemanfaatan strategi ini telah sesui dengan kaidah pembelajaran diskusi online, tercapainya tujuan pembelajaran yang telah ditetapkan, dan tentu saja sesuai dengan konsepsi dari teknologi pendidikan itu sendiri. Secara singkat, penulis tertarik untuk meneliti dan mengamati lebih lanjut tentang pemanfaatan online group discussion pada mata kuliah teknologi pendidikan.

Penulisan artikel ini tidak dapat mencakup penjelasan secara mendetail layaknya sebuah karya ilmiah yang merupakan hasil penelitian, dikarenakan metode online grup discussion baru akan diimplementasikan. Hasil secara mendetail akan dilanjutkan pada penulisan artikel berikutnya. Tujuan utama dari penulisan artikel ini adalah untuk menyampaikan kepada khalayak bahwa ada potensi lain yang bisa digali dan implementasikan yakni berupa online group discussion, merupakan salah satu contoh penerapan pada Mata Kuliah Teknologi Pembelajaran Fisika.

\section{SIMPULAN}

Penulisan artikel ini berangkat dari ketertarikan penulis pada metode pembelajaran diskusi. Berdasarkan metode, ini kemudian ditemukan bahwa diskusi itu sendiri adalah konsep belajar yang sebenarnya. Alasannya adalah bahwa sebenarnya pembelajaran adalah mengkonstruksi pemikiran dengan menggabungkan berbagai pemikiran orang lain yang kemudian dibentuk kembali berupa pengetahuan baru yang sesuai dengan pembelajaran outhentic atau yang terbangun dari pengalaman pribadi pebelajar. Proses rekonstruksi atas pembelajaran seperti itu tetap akan terjadi sekalipun pebelajar tidak berada dalam satu ruangan dengan teman diskusinya yang lain dan pakarnya atau dalam arti tidak selalu harus selalu dalam keadaan bertatap muka. Bagaimanapun pembelajaran tersebut harus tetap terjadi sekalipun harus terpisah secara jarak dan waktu, dan sebagai solusinya adalah dengan diskusi online (online group discussion). Tetapi, sangat disadari sekali bahwa ketersediaan rangkaian jaringan internet dan perangkatnya yang ada di kampus tempat penulis mengimplementasikan pembelajaran masih sangat terbatas. Namun, hal ini tidak mengurangi semangat untuk terus berbenah dan melakukan perbaikan ke depannya.

\section{DAFTAR PUSTAKA}

Asalla, L. K., Maria, N., \& Hannesto, R. (2014). Pengaruh Penerapan Coi Framework pada Pembelajaran Online Terhadap Peningkatan Pemahaman (Sub kategori Cognitive Presence) Mahasiswa. ComTech: Computer, Mathematics and Engineering Applications, 5(1), 213-223. 
Djuniadi, D. (2012). Fitur Motivasi Pembelajran Online dengan Pendekatan Pre-defined Set. Jurnal Pendidikan Vokasi, 2(1).

Kusumaningrum, D. A., \& Marpanaji, E. (2014). Pengembangan ELearning Dengan Pendekatan Teori Kognitif Multimedia Pembelajaran Di Jurusan TKJ SMK Muhammadiyah 2 Yogyakarta. Jurnal Inovasi Teknologi Pendidikan, 1(1), 2839.

Gredler, Margaret E. Bell. (2009). Learning and intruction Theory into Practice, Pearson Education, Inc.

Miarso, Y. (2004). Menyemai Benih Teknologi Pendidikan, Jakarta: Kencana Prenada media Group.
Prawiradilaga, Dewi Salma, dkk. (2013). Mozaik Teknologi Pendidikan, e-learning. Jakarta: Kencana. Prenadamedia Group. Smaldino, Sharon E., Deborah L Lowther, \& James D. Russel. (2007). Instructional Technology and media for Learning. New Jersey: Pearson education, Inc.

Suroyo, \& Ismarwati, A. (2006). The Challenges Of Knowledge Construction Through EModerating At Universitas Terbuka, Indonesia Case Study: Tutorial Online In Mathematics Courses. Asian Association of Open Universities Journal, 2(1), 21-35. 